\title{
Role of Customer Brand Loyalty with Reference to Big Bazaar-An Empirical Research
}

\author{
R S Ch Murthy Chodisetty, Siddhani Reddy
}

\begin{abstract}
As customer's tastes and preferences area unit dynamical, the market situation is additionally dynamical from time to time. Today's market situation is incredibly totally different from that of the market situation before 1990. There are several factors chargeable for the dynamical market situation. It's the dynamical tastes and preference of client that has bought during a modification within the market. Financial gain level of the folks has modified; life designs and socio-economic class of individuals have fully changed currently than that of past days. There has been a shift within the market demand in today's world. Technology is one amongst the most important factors that is chargeable for this paradigm shift within the mark. This paper focus on customer brand loyalty, study the factors influencing Customer store loyalty in big bazaar. This reason focus on unearthing those hidden factors which will benefit the retail manager.
\end{abstract}

Key words - customer loyalty, Brand Loyalty, card holders, satisfaction, Factors.

JEL Codes-A-11, A-12, A13-, A14, A-15

\section{INTRODUCTION:}

My study relies on a survey done on customers of a supermarket named huge bazaar. Huge bazaar could be a new variety of market that came into existence in Bharat since 1994. It's a sort of market wherever numerous types of merchandise area unit offered below one roof. My study is on determinant the customer's shopping for behavior of customer's in huge bazaar and therefore the satisfaction level of shoppers in huge bazaar. My study can ascertain the present standing of huge bazaar and confirm wherever it stands within the current market.

\section{REVIEW OF LITERATURE:}

1. Mari sreenivasulu, Dr.G.Janardhan \&Dr. Mamilla Rajasekar(2016): in their study titled Customer loyalty towards corporate retail store A case study of big bazaar retail store in Bangalore city.Brand loyalty is the consumers emotionally charged decision to purchase a specific brand, again and again, recent studies focused on loyalty concept in goods as well as service sector. All the factors showed positive relationships with brand loyalty except store environment and design.

2. Dr.MU. Subramanian S. Chandrasekaran\& Ms. Loganayagi (2016): in their study titled on A study on consumer behavior towards big bazaar, Chennai, Tamilnadu, India. The objective of the studyidentifies the consumer behavior towards the product and also

Revised Manuscript Received on April 12, 2019.

R S Ch Murthy Chodisetty, Assistant Professor, School of Management Studies, Sreenidhi Institute of Science and Technology, Hyderabad,Telangana, India.Chodisetty. (E-mail: b4u@gmail.com)

Siddhani Reddy, Student, B.Tech -III Year, Department of ECE, Sreenidhi Institute of Science and Technology, Hyderabad.Telangana, India.(E-mail: siddhanireddy@gmail.com) the various factors affecting consumer's satisfaction. They found that big bazaar satisfying customer needs and wants and the customer satisfied with the variety of products.

3. Japes kumar j. patel, Rajesh KumarM.choudary and DR. Prashantmakwan (2014): in their study titledAnalysis of the sales checkout operation in big bazaar using queue simulation. This paper describes a queuing simulation for multiple server processes as well as for single queue models. This study requires empirical data which may include the variables like, arrival time in the queue of checkout operating unit, departure time service time etc..

4. Deval B. Patel (2014): in his study titled A case study on customer relationship management at big bazaar in surat. CRM provides long-term relationship building with customers at an enterprise-wide level. Big bazaar aim is to provide "sab sesasta" which means at cheapest rates. Big bazaar giving value for money to its customer.

5. Ramya,K and janani.P(2013):in their study titled $A$ study on customers preferences and satisfaction towards big bazaar with reference to Coimbatore city of India.The main objective of this study is to analyze why they customers prefer the organized retail shop for their purchase instead of unorganized retail shop and their satisfaction level. The collected data is analyzed and interpreted with the help of suitable statistical tool and accordingly the findings and suggestion are constructed which is considered to be an important part of the project.

6. Dr. Muzzafar ahmad bhat, anit kumar (2013): in their study titled Customer perception and its implications modern retail sector: a case study of big bazaar. This study aims to highlight the cognitive thinking of customers which big bazaar has been targeting with immense and rigorous manner. Perception is one of the main aspects which has to be taken seriously by the present retailers. This study aims to highlight the perception of customers towards big bazaar.

7. Dr. Jaideo lanjewar(2013): in his study titled Study of customer perception towards big bazaar. The main objective aims at identifying the profile of this new Indian customer, how they purchase, what are the factors that influence the consumer behavior towards big bazaar. They found that their biggest client base is youngsters, who visited big bazaar mainly to shop clothes and food items and preferred big bazaar.

Published By:

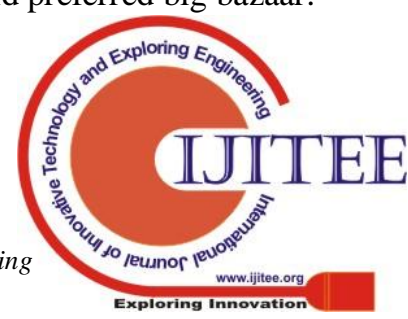


8. Bhawana Gupta, Dr. Amit malik (2012): in their study titled Customer expectation and perception about big bazaar. With the increase in per capita income, demographical changes accompanied with improvement in the standards of living and change in the pattern of consumption a large number of multinational retail chains find India as their place for business in India.

\section{II.1. Objective of the study:}

1. To study the factors influencing Customer store loyalty in Big bazaar with regard to different types of card holders.

2. To analyze the effect of Loyalty program on building customer loyalty.

II.2. Hypothesis of the study:

1. HO:There is no significant impact of type of card holders and customer loyalty

2. H1:There is a significant impact of type of card holders and customer loyalty

\section{II.3.VARIABLES:}

Dependent Variable:
1. Customer store loyalty

Independent Variables:

1. Reliability ( never say no philosophy)

2. Discount offers

3. Waiting time

4. easiness in finding the products

\section{II.4.NEED FOR THE STUDY:}

1. The customer may come to retail outlet for many reason but particularly the retail managers wanted to know which the reasons that pull the customer into store are.

2. This reason focus on unearthing those hidden factors which will benifitthe retail manager

\section{II.5.Research methodology:}

The present study aims to analyze the customer loyalty towards the stone of big bazaar. For the purpose of study, secondary data will be collected from the big bazaar.

\section{DATA ANALYSIS AND RESULTS:}

Descriptive analysis:

\begin{tabular}{|c|c|c|c|c|c|c|c|c|}
\hline \multicolumn{9}{|c|}{ Descriptive } \\
\hline \multicolumn{9}{|l|}{ Loyalty } \\
\hline & \multirow[t]{2}{*}{$\mathrm{N}$} & \multirow[t]{2}{*}{ Mean } & \multirow[t]{2}{*}{$\begin{array}{c}\text { Std. } \\
\text { Deviation }\end{array}$} & \multirow[t]{2}{*}{$\begin{array}{l}\text { Std. } \\
\text { Error }\end{array}$} & \multicolumn{2}{|c|}{$\begin{array}{l}\text { 95\% Confidence Interval for } \\
\text { Mean }\end{array}$} & \multirow[t]{2}{*}{ Minimum } & \multirow[t]{2}{*}{ Maximum } \\
\hline & & & & & Lower Bound & Upper Bound & & \\
\hline Silver & 36 & 41.9167 & 9.14448 & 1.52408 & 38.8226 & 45.0107 & 20.00 & 59.00 \\
\hline Gold & 26 & 44.8846 & 8.32503 & 1.63267 & 41.5221 & 48.2472 & 30.00 & 62.00 \\
\hline Platinum & 19 & 44.1053 & 9.20685 & 2.11220 & 39.6677 & 48.5428 & 21.00 & 61.00 \\
\hline Total & 81 & 43.3827 & 8.89602 & .98845 & 41.4156 & 45.3498 & 20.00 & 62.00 \\
\hline
\end{tabular}

\begin{tabular}{|l|r|r|r|c|c|}
\hline \multicolumn{7}{|c|}{ ANOVA } \\
\hline Loyalty & Sum of Squares & df & Mean Square & F & Sig. \\
\hline & 145.942 & 2 & 72.971 & .920 & .403 \\
\hline Between Groups & 6185.193 & 78 & 79.297 & & \\
\hline Within Groups & 6331.136 & 80 & & & \\
\hline Total & 630 & & & \\
\hline
\end{tabular}

\begin{tabular}{|c|c|c|c|c|c|c|}
\hline \multicolumn{7}{|c|}{ Multiple Comparisons } \\
\hline \multicolumn{7}{|l|}{$\begin{array}{l}\text { Loyalty } \\
\text { LSD }\end{array}$} \\
\hline \multirow[t]{2}{*}{ (I) type of card } & \multirow[t]{2}{*}{$(\mathrm{J})$ type of card } & \multirow[t]{2}{*}{ Mean Difference (I-J) } & \multirow[t]{2}{*}{ Std. Error } & \multirow[t]{2}{*}{ Sig. } & \multicolumn{2}{|c|}{$95 \%$ Confidence Interval } \\
\hline & & & & & Lower Bound & Upper Bound \\
\hline \multirow[t]{2}{*}{ Silver } & Gold & -2.96795 & 2.29186 & .199 & -7.5307 & 1.5948 \\
\hline & Platinum & -2.18860 & 2.52512 & .389 & -7.2157 & 2.8385 \\
\hline \multirow[t]{2}{*}{ Gold } & Silver & 2.96795 & 2.29186 & .199 & -1.5948 & 7.5307 \\
\hline & Platinum & .77935 & 2.68765 & .773 & -4.5713 & 6.1300 \\
\hline \multirow[t]{2}{*}{ Platinum } & Silver & 2.18860 & 2.52512 & .389 & -2.8385 & 7.2157 \\
\hline & Gold & -.77935 & 2.68765 & .773 & -6.1300 & 4.5713 \\
\hline
\end{tabular}

\begin{tabular}{|l|l|r|r|}
\hline \multicolumn{1}{|c|}{} & & \multicolumn{1}{|c|}{ Frequency } & \multicolumn{1}{c|}{ Percent } \\
\hline Valid & Male & 43 & 54 \\
\cline { 2 - 4 } & Female & 37 & 46 \\
\cline { 2 - 4 } & Total & 80 & 100.0 \\
\hline
\end{tabular}




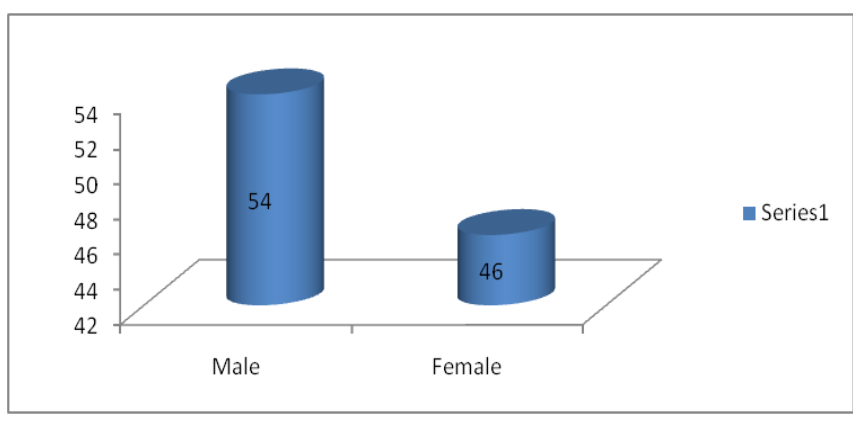

Interpretation:

Gender specification is belongs to indentified The evidence from this bar chart shows that $54 \%$ Males Respondents and 46\% Female Respondents are taken for the study

\begin{tabular}{|l|r|r|}
\hline & Frequency & Percent \\
\hline $20-25$ & 43 & 53.8 \\
\hline $25-30$ & 15 & 18.8 \\
\hline $30-35$ & 12 & 15.0 \\
\hline
\end{tabular}

\begin{tabular}{|l|l|r|r|r|r|}
\hline & & Frequency & Percent & \multicolumn{1}{c|}{ Valid Percent } & \multicolumn{1}{c|}{$\begin{array}{c}\text { Cumulative } \\
\text { Percent }\end{array}$} \\
\hline Valid & Student & 18 & 22.5 & 22.5 & 22.5 \\
\cline { 2 - 6 } & Employed & 34 & 42.5 & 42.5 & 65.0 \\
\cline { 2 - 6 } & Self Employed & 15 & 18.8 & 18.8 & 83.8 \\
\cline { 2 - 6 } & Home Maker & 6 & 7.5 & 7.5 & 91.3 \\
\cline { 2 - 6 } & Retired & 3 & 3.8 & 3.8 & 95.0 \\
\cline { 2 - 6 } & Others & 4 & 5.0 & 5.0 & 100.0 \\
\cline { 2 - 6 } & Total & 80 & 100.0 & 100.0 & \\
\hline
\end{tabular}

\section{Percent of Profession of the respondend}

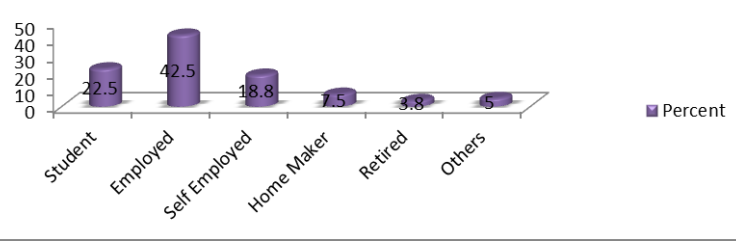

\begin{tabular}{|l|r|r|}
\hline Above 40 & 10 & 12.5 \\
\hline Total & 80 & 100.0 \\
\hline
\end{tabular}

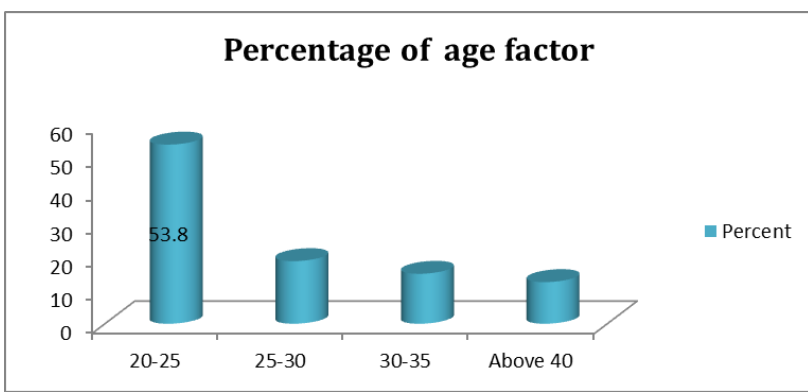

Interpretation:

Gender specification It is clear from the information given in the table and the bar chart that the ages of 20-25 Years respondent are more than the other ages like 25-30, $30-35$ and above 40 years.

Interpretation:

\begin{tabular}{|l|l|c|c|c|c|}
\hline & & Frequency & Percent & Valid Percent & $\begin{array}{c}\text { Cumulative } \\
\text { Percent }\end{array}$ \\
\hline \multirow{5}{*}{ Valid } & Once in a week & 12 & 15.0 & 15.0 & 15.0 \\
\cline { 2 - 6 } & Twice in a week & 11 & 13.8 & 13.8 & 28.8 \\
\cline { 2 - 6 } & Once in a Month & 23 & 28.8 & 28.8 & 57.5 \\
\cline { 2 - 6 } & Only on offer days (Big days, Wednesday bazaar) & 14 & 17.5 & 17.5 & 75.0 \\
\cline { 2 - 6 } & 5 & 20 & 25.0 & 25.0 & 100.0 \\
\cline { 2 - 6 } & Total & 80 & 100.0 & 100.0 & \\
\hline
\end{tabular}

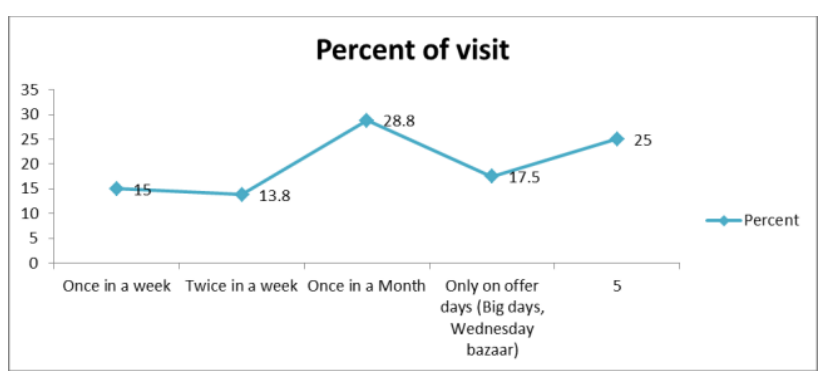

Above table and chart belongs to profession of responded, It is clear from the information given in this Bar Graph that the Employees are more responded than the Self-employed, Student, home maker, retired and other.

\section{Interpretation:}

It is clear from the Pie diagram that the most of the Customer visit big bazar only once in a month. 


\section{FINDINGS:}

- In the statistical test it is proved that there is no significant relation between the type of the card holder and customer loyalty.

- The study reveals that majority of the customers from the sample hold silver cards than the other type of cards

- The study reveals most of the card users from the sample belong to the age group between 20-25

- The study indicates that most of the people are visiting the store once in a Month.

- The major item bought by the customers is Clothing.

\section{CONCLUSION:}

Today most of the retail out let are engaged in loyalty programs for increasing the customer traffic and to build the store loyalty with a vision of extending the customer life time with the store which will decrease the marketing expenditure on each customer, in this regard big bazaar believed in offering loyalty programs which enhance the customer store loyalty. There is a very peculiar situation that though majority of the card holders have opted for silver, but the study reveals that the customers of the gold card have proved to be more loyal. In this scenario of increasing retail density bog bazaar has been offering various other schemes and facilities to the customers for strengthen their loyal base, and they are also offering special big Wednesday offer to instigate the middleweek-dull sales.

\section{REFERENCES:}

1. http://iosrjournals.org/iosr-jbm/papers/Vol16issue4/Version-6/A016460108.pdf

2. http://ifsmrc.org/sites/default/files/journals/pdf/1.\%20 IFSMRC\%20\%2001V3N5\%20JJ2015\%20A\%20stud y\%20on\%20consumer\%20behaviour\%20towards\%20 Big\%20baazar\%20chennai.pdf

3. https://www.noexperiencenecessarybook.com/1qqOO /analysis-of-the-sales-checkout-operation-in-bigbazar-using.html

4. https://www.worldwidejournals.com/paripex/file.php? val=October_2012_1350555754_5fb67_44.pdf

5. : http://www.ijims.com/uploads/38e123783480ca47f5f 410pdf.pdf

6. http://www.indusedu.org/pdfs/IJRIME/IJRIME_897_ 25042.pdf

7. http://abhinavjournal.com/journal/index.php/ISSN2277-1166/article/view/544/pdf_126

8. http://www.indusedu.org/pdfs/IJRIME/IJRIME_897_ 25042.pdf 